\title{
Epigenetyka jako obiecująca dziedzina nauki w walce z nowotworami głowy i szyi
}

\section{Epigenetics as a promising scientific field in the context of head and neck cancer treatment}

\author{
Kamila Romanowska ${ }^{1,2}$, Wojciech Golusiński ${ }^{1}$ \\ ${ }^{1}$ Katedra i Klinika Chirurgii Gtowy, Szyi i Onkologii Laryngologicznej, Uniwersytet Medyczny im. Karola Marcinkowskiego w Poznaniu, \\ Wielkopolskie Centrum Onkologii \\ ${ }^{2}$ Zakład Fizyki Medycznej, Pracownia Radiobiologii, Uniwersytet Medyczny im. Karola Marcinkowskiego w Poznaniu, \\ Wielkopolskie Centrum Onkologii
}

\section{Streszczenie}

Nowotwory głowy i szyi (HNC, ang. head and neck cancer) stanowią obecnie szóstą najczęściej występującą chorobę nowotworową na Świecie. Każdego roku diagnozuje sie c ponad pół miliona nowych przypadków zachorowań. Ze względu na duza róznorodność genetyczna i histologiczna nowotworów głowy i szyi, ich patogeneza opiera sięna wielu złozonych procesach obejmujacych akumulację zmian zarówno genetycznych, jak i epigenetycznych. Modyfikacje epigenetyczne wysteppujace w nowotworach głowy i szyi obejmuja metylacjęDNA, modyfikacje histonów, aktywność niekodujacych RNA oraz metylacjęRNA. Niektóre zmiany epigenetyczne promuja powstawanie i rozwój raka poprzez kontrolowanie mechanizmów ekspresji wielu genów kluczowych dla procesu kancerogenezy. W związku z tym modyfikacje te mogą być wykorzystane jako biomarkery diagnostyczne pacjentów onkologicznych oraz stanowić cele ukierunkowanych terapii przeciwnowotworowych.

\begin{abstract}
Head and neck cancer (HNC) is the sixth most prevalent cancer worldwide, representing more than a half million of the new cases every year. Due to high genetic and histologic diversity of head and neck cancers, their molecular pathogenesis is based on complex process including disorders driven not only by accumulation of genetic alterations, but also changes in epigenetic landscape. The epigenetic variations in HNC include DNA methylation, histone modifications, non-coding RNA activity and RNA methylation. Some of the epigenetic alterations promote cancer formation and progression by controlling the expression machinery. Consequently, those modifications can be used as biomarkers for clinical detection and surveillance of cancer and will reveal new therapeutic opportunities for cancer patients.
\end{abstract}

Adres do korespondencji

Kamila Romanowska

Katedra i Klinika Chirurgii Głowy

Uniwersytet Medyczny im. Karola Marcinkowskiego w Poznaniu

e-mail: kamromanowska@gmail.com 
Stowa kluczowe: nowotwory głowy i szyi, epigenetyka, metylacja DNA, modyfikacje histonów, aktywność niekodujących RNA, metylacja RNA

Keywords: head and neck cancer, epigenetic, DNA methylation, histone modifications, non-coding RNA activity, RNA methylation

\section{Nowotwory głowy i szyi}

Nowotwory głowy i szyi (HNC, ang. head and neck cancer) stanowią obecnie szóstą najczęściej występującą chorobę nowotworową na Świecie. Co roku, szacuje się ponad 650000 nowych przypadków zachorowań oraz około 300 ooo zgonów z powodu tego nowotworu [1]. Do głównych przyczyn powstawania i rozwoju raka głowy i szyi zalicza się palenie tytoniu oraz spożywanie alkoholu $[2,3]$. Ponadto, jednym z czynników, który często towarzyszy zachorowaniu jest infekcja wirusem brodawczaka ludzkiego (HPV, ang. human papillomavirus) lub wirusem Epsteina-Barra [4,5]. Leczenie nowotworów głowy i szyi obejmuje chirurgiczną eradykację, radioterapię (RT, ang. radiotheraphy) oraz chemioterapię (CT, ang. chemotheraphy). Dodatkowo, w praktyce klinicznej stosuje się również lek immunoterapeutyczny- cetuksymab, który jest przeciwciałem monoklonalnym skierowanym na receptor nabłonkowego czynnika wzrostu (EGFR, ang. epidermal growth factor receptor) [6]. Wybór metody leczenia zależy od rodzaju i stadium guza, możliwych skutków ubocznych i ogólnego stanu zdrowia pacjenta. Niestety ze względu na dużą różnorodność molekularną i histologiczną nowotworów głowy i szyi, klasyczne terapie podobnie jak immunoterapia mają ograniczoną skuteczność. Molekularna patogeneza guzów głowy i szyi składa się z szeregu zaburzeń, które wynikają z akumulacji zmian na podłożu genetycznym. Te zmiany powodują nieprawidłowe funkcjonowanie kluczowych szlaków komórkowych oraz nabieranie przez komórki prawidłowe cech komórek nowotworowych. Do głównych szlaków komórkowych, które charakteryzują się nieprawidłowym funkcjonowaniem w nowotworach głowy i szyi można zaliczyć proliferację, różnicowanie i przeżycie komórek, procesy związane z przerzutowaniem i z opornością na leczenie [7]. Obecnie, mimo coraz większego poznania zarysów genetycznych nowotworów nadal ciężko jednoznacznie wskazać na konkretną przyczynę ich powstawania. W konsekwencji nie istnieją również wysoce specyficzne terapeutyki genetyczne umożliwiające zwalczanie chorób nowotworowych, w tym nowotworów głowy i szyi. Istotny jest fakt, że karcynogeneza HNC napędzana jest nie tylko przez nagromadzenie zmian genetycznych, ale także przez zmiany w krajobrazie epigenetycznym. Z roku na rok rośnie liczba badań naukowych, które wskazują, że zmiany epigenetyczne stanowią bardzo ważny czynnik w powstaniu i progresji guza i tym samym stały się celem dla nowych terapii przeciwnowotworowych.

\section{Epigenetyka}

Epigenetyka (z greckiego „epi”-nad) jest dziedziną nauki, która jak sama nazwa wskazuje znajduję się w hierarchii nad genetyką, często nazywana jest również „drugim kodem”, zaraz obok kodu genetycznego. Epigenetyka zajmuje się dziedzicznymi modyfikacjami w obrębie pojedynczych nukleotydów, które warunkują aktywację genów, odpowiadają za dostępność DNA dla czynników transkrypcyjnych oraz wpływają na upakowanie sekwencji DNA w bardziej złożone struktury [8]. Dodatkowo, epigenetyka wskazuje na kluczowy związek między czynnikami środowiskowymi a funkcjonowaniem genomu. Pojęcie „epigenetyka” zostało wprowadzone w 1942 roku przez Conrada Waddingtona, brytyjskiego biologa rozwoju [9]. Waddington zaprojektował schemat „epigenetyczny krajobraz”, który wyjaśnia fenomen w jaki sposób z jednej komórki macierzystej powstaje szereg innych komórek ludzkiego ciała, które różnią się funkcją i lokalizacją (fenotypem), ale nie różnią się sekwencją DNA (genotypem). Epigenetyka odpowiada również za przebieg kluczowych procesów na etapie embrionalnym takich jak imprinting genomowy (lub piętnowanie genowe) oraz inaktywację chromosomu X [10].

\section{- 2.1. Modyfikacje epigenetyczne w nowotworach głowy i szyi}

Modyfikacje epigenetyczne w nowotworach głowy i szyi obejmują metylację DNA, modyfikację histonów, aktywność niekodujących RNA, a także metylację RNA (Figura 1) [11-12]. Ze względu na to, że regulują one 
ekspresję genów supresorowych nowotworów (TSG, ang. tumor suppresor genes) i onkogenów, stały się one przedmiotem zainteresowania w badaniach nad rakiem, także w kontekście spersonalizowanych strategii terapeutycznych.

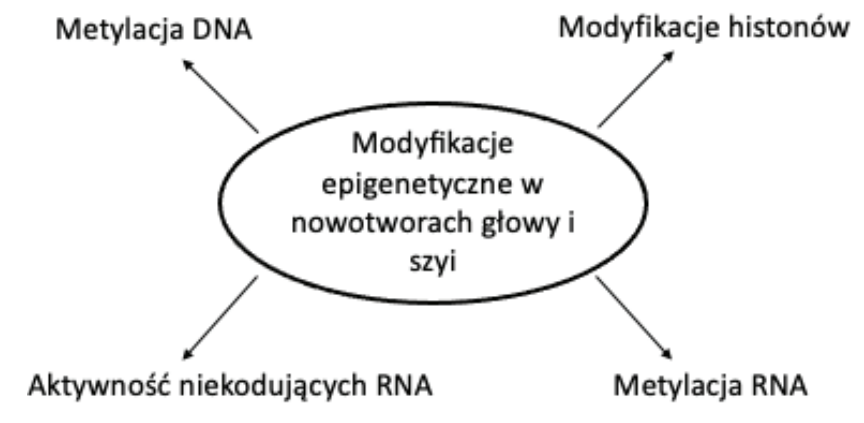

Figura 1. Modyfikacje epigenetyczne występujące w nowotworach głowy i szyi.

\section{Metylacja DNA}

MetylacjaDNAjestjednąznajlepiejpoznanych modyfikacjiepigenetycznych,którapoleganakowalencyjnym dodaniu grupy metylowej do pirymidynowego pierścienia cytozyny w pozycji piątej, w wyniku czego powstaje 5-metylocytozyna (5-mC). U ssaków 5-mC akumuluje się w regionach DNA bogatych w dinukleotydy CpG (tak zwane wyspy $\mathrm{CpG}$ ), w obrębie których 70-80\% cytozyn jest metylowanych [13]. Około 60\% wysp CpG jest zlokalizowanych w regionach promotorów genów [14]. Obecność metylacji DNA w promotorach genów blokuje dostęp i wiązanie czynników transkrypcyjnych co w konsekwencji prowadzi do braku ich ekspresji. Jedną z charakterystycznych cech nowotworów jest globalna hipometylacja (demetylacja) DNA i specyficzna lokalna hipermetylacja (nadmierna metylacja) wysp CpG [15]. Hipometylacja w tkankach nowotworowych występuje głównie na sekwencjach wielokrotnie powtórzonych (np. SAT2) i retrotranspozonach (np. LINE-1 i ALU) oraz prowadzi do niestabilności genomowej i aktywacji onkogenów. Z kolei, miejscowa hipermetylacja DNA jest zwykle związana z wyspami CpG w promotorach genów supresorowych nowotworów [16]. U pacjentów z nowotworami głowy i szyi zidentyfikowano wiele nieprawidłowo zmetylowanych genów, w porównaniu do pacjentów zdrowych. W literaturze naukowej, obecnie znajduje się wiele badań wskazujących związek pomiędzy wzorem metylacji DNA wybranych genów a powstawaniem i progresją nowotworu. Te wyniki oparte są na danych klinicznych pacjentów i wskazują na potencjał zmian w metylacji DNA jako potencjalnego biomarkera progresji choroby o szczególnym znaczeniu diagnostycznym.

\section{Modyfikacje histonów}

Kolejną istotną zmianą epigenetyczną z punktu widzenia powstania nowotworów głowy i szyi jest modyfikacja histonów, w szczególności ich metylacja i acetylacja. Histony są podstawowymi białkami znajdującymi się w jądrach komórek eukariotycznych, które pakują i porządkują DNA w jednostki strukturalne zwane nukleosomami. Acetylacja histonów jest ważnym mechanizmem wpływającym na strukturę chromatyny i regulującym ekspresję genów [17,18]. Acetylotransferaza histonowa (HAT, ang. histone acetyltransferase) jest enzymem odpowiedzialnym za przyłączanie grupy acetylowej do określonych reszt lizyny, głównie na histonie $\mathrm{H}_{3}$ i H4 [19]. Acetylacja histonów neutralizuje dodatni ładunek reszt lizyny i rozluźnia strukturę chromatyny. Proces ten jest skorelowany z rekrutacją koaktywatorów transkrypcji i zwiększonym wydłużaniem transkrypcji wykonywanym przez polimerazę RNA II [17]. Z kolei, metylacja histonów występuje na reszcie lizyny (Lys lub K) lub argininy (Arg lub R). Modyfikacje te można rozpoznać analizując dodatnie i ujemnne regulatory aktywujące lub hamujące transkrypcję genów [20]. W przypadku pacjentów z nowotworami głowy i szyi zaobserwowano zmiany w poziomie acetylacji i metylacji kluczowych histonów w porównaniu do pacjentów zdrowych. Te zmiany powodują między innymi aktywację przejścia epitelialno-mezenchymalnego komórek nowotworowych, które zapoczątkowuje procesy przerzutowana, 
wzmożony wzrost guza oraz oporność na konwencjonalne leczenie [21-23].

\section{Niekodujące RNA}

Istotne zmiany epigenetyczne wywołuje również aktywność niekodujących RNA (ncRNA, ang. non-coding $R N A$ ), które można podzielić na małe (mniej niż 200 nukleotydów) i duże ncRNA. Małe ncRNA obejmują małe jądrowe RNA (snoRNA, ang. small nucleolar RNA), RNA oddziałujące z PIWI (piRNA), małe interferujące RNA (siRNA, ang. silencing RNA) i mikroRNA (miRNA). Działanie ncRNA opiera się na wyciszaniu genów transkrypcyjnych i potranskrypcyjnych poprzez specyficzne parowanie zasad z sekwencjami docelowymi [24]. miRNA mogą działać jako supresory nowotworów lub onkogeny (oncomiR) i odgrywać kluczową rolę w angiogenezie, proliferacji komórek i apoptozie [25]. Poza tym istnieje kilka miRNA wpływających na niestabilność genów, unikanie odporności immunologicznej, przerzuty nowotworów oraz chemoi radiooporność komórek nowotworowych. Wysokoprzepustowa metaanaliza ekspresji miRNA pokazuje długą listę cząsteczek związanych ze złym rokowaniem, niższym przeżyciem i przerzutami nowotworów głowy i szyi [26]. Z tego względu, mechanizm interferencji RNA stał się cennym narzędziem badawczym umożliwiającym pełniejsze zrozumienie mechanizmów patogenezy nowotworów i wskazanie nowych celi terapeutycznych [27].

\section{Metylacja RNA}

Ostatnią istotną modyfikacją epigenetyczną, pod kątem nowotworów głowy i szyi, jest metylacja RNA. Ta zmiana jest najbardziej rozpowszechnioną, dynamiczną i konserwatywną modyfikację transkrypcji spośród ponad 100 różnych modyfikacji chemicznych RNA [28,29]. Występuję na adenozynie w pozycji szóstej azotu (m6A) w RNA, zwykle w pobliżu kodonu STOP i regionu 3'UTR zawierającego sekwencję 5'-RRACH-3' [3032]. Badania naukowe sugerują, że modyfikacja ta jest zaangażowana we wszystkie etapy przetwarzania RNA, w tym eksport z jądra komórkowego poprzez modulację translacji aż do degradacji RNA i inicjacji biogenezy miRNA. Zmiany w procesie metylacji RNA przyczyniają się do wzrostu guza, jego progresji, inwazji oraz migracji komórek nowotworowych. Zaburzenia w obrębie tych procesów zaobserwowano w ostrej białaczce szpikowej [33], glejaku [34], raku płuca [35], raku piersi [36], raku wątroby [37], raku pęcherza moczowego [38] raku trzustki [39] oraz nowotworach głowy i szyi [40]. Biorąc pod uwagę kluczową rolę metylacji RNA w metabolizmie komórkowym i niekwestionowane skutki zaburzeń w tym procesie dotyczących karcynogenezy, metylacja RNA oraz mechanizmy związane z metylacją RNA z pewnością zostaną w przyszłości bardziej szczegółowo opisane i rozpatrywane jako kandydaci nowego, obiecującego biomarkera nowotworów głowy i szyi.

\section{Podsumowanie}

Obecnie modyfikacje epigenetyczne wzbudzają duże zainteresowanie w rozwoju i progresji nowotworów głowy i szyi. Szczegółowa charakterystyka zmian epigenetycznych w nowotworach może dostarczyć wiedzę na temat nowych, krytycznych czynników prognostycznych i predykcyjnych, które mogą być użyte w kontekście leczenia i terapii przeciwnowotworowych. Ponadto, szczegółowe profilowanie całego epigenomu może poprawić zarówno diagnostykę pacjentów z rakiem, jak i ukierunkowaną spersonalizowaną terapię.

\section{Finansowanie/ Financial suport}

This work was funded by The Greater Poland Cancer Centre, grant number 31/o8/2020/PRB/WCO/oo8

\section{Konflikty interesu / Conflicts of interest}

Nie występują / None 


\section{Piśmiennictwo/References}

[1] Bray, F.; Ferlay, J.; Soerjomataram, I. Global Cancer Statistics 2018 : GLOBOCAN Estimates of Incidence and Mortality Worldwide for 36 Cancers in 185 Countries. CA Cancer J. Clin. 2018, 68, 394-424. doi: 10.3322/caac. 21492

[2] Franceschi, S., Talamini, R.; Barra, S.; Barón, A.E.; Negri, E.; Bidoli, E.; Serraino, D.; La Vecchia, C. Smoking and drinking in relation to cancers of the oral cavity, pharynx, larynx, and esophagus in northern Italy. Cancer Res. 1990, 50, 6502-6507.

[3] Argiris, A.; Karamouzis, M.V.; Raben, D.; Ferri,s R.L. Head and neck cancer. Lancet 2oo8, 371, 16951709. doi: 10.1016/So140-6736(08)60728-X

[4] Gillison, M.L.; Koch, W.M.; Capone, R.B.; Spafford, M.; Westra, W.H.; Wu, L. et al. Evidence for a causal association between human papillomavirus and a subset of head and neck cancers. J. Natl. Cancer Inst. 2000, 92, 709-720. doi: 10.1093/jnci/92.9.709

[5] Sisk, E.A.; Bradford, C.R.; Carey, T.E.; Paulino, A.; Robertson, E. Epstein-Barr virus detected in a head and neck squamous cell carcinoma cell line derived from an immunocompromised patient. Arch. Otolaryngol. Head Neck Surg. 2003, 129, 1115-1124. doi: 10.1001/archotol.129.10.1115

[6] Moskovitz, J.; Moy, J.; Ferris, R.L. Immunotherapy for Head and Neck Squamous Cell Carcinoma. Curr. Oncol. Rep. 2018, 2O, 22. doi: 10.1007/s11912-018-0654-5

[7] Allen, C.T.; Ricker, J.L.; Chen, Z.; Van Waes, C. Role of activated nuclear factor-kappaB in the pathogenesis and therapy of squamous cell carcinoma of the head and neck. Head Neck 2007, 29, 959-971. doi: 10.1002/hed.20615

[8] Bird, Adrian. Perceptions of Epigenetics. Nature, 2007, 447, 396-98. doi: 10.1038/natureo5913

[9] Tronick E, Hunter RG. Waddington, Dynamic Systems, and Epigenetics. Front Behav Neurosci. 2016;10:107. Published 2016 Jun 10. doi:10.3389/fnbeh.2016.00107

[10] Payer B, Lee JT, Namekawa SH. X-inactivation and X-reactivation: epigenetic hallmarks of mammalian reproduction and pluripotent stem cells. Hum Genet. 2011;130(2):265-280. doi:10.1007/so0439-0111024-7

[11] Castilho, R.M.; Squarize, C.H.; Almeida, L.O. Epigenetic Modifications and Head and Neck Cancer: Implications for Tumor Progression and Resistance to Therapy. Int. J. Mol. Sci. 2017, 18, 1506. doi: 10.3390/ijms18071506

[12] Zhang, P.; He, Q.; Lei, Y.; Li, Y.; Wen, X.; Hong, M. et al. m6A-mediated ZNF750 repression facilitates nasopharyngeal carcinoma progression. Cell Death Dis. 2018, 9, 1169. doi: 10.1038/s41419-018-1224-3

[13] Lorincz, M.C.; Dickerson, D.R.; Schmitt, M.; Groudine, M. Intragenic DNA methylation alters chromatin structure and elongation efficiency in mammalian cells. Nat. Struct. Mol. Biol. 2004, 11, 1068-1075. doi: $10.1038 / \mathrm{nsmb840}$

[14] Antequera, F. Structure, function and evolution of $\mathrm{CpG}$ island promoters. Cell Mol. Life Sci. 2003, 6o, 1647-1658. doi: 10.1007/soo018-003-3088-6

[15] Suzuki, M.M.; Bird, A. DNA methylation landscapes: provocative insights from epigenomics. Nat. Rev. Genet. 2008, 9, 465-476. doi: 10.1038/nrg2341

[16] Robertson, K. DNA methylation and human disease. Nat. Rev. Genet. 2005, 6, 597-610. doi: 10.1038/ nrg1655.

[17] Verdone,L.; Caserta,M.; Di Mauro,E. Roleofhistoneacetylation in thecontrol of geneexpression. Biochem. Cell Biol. 2005, 83, 344-353. doi: 10.1139/005-041

[18] Annunziato, A.T.; Hansen, J.C. Role of histone acetylation in the assembly and modulation of chromatin structures. Gene Expr. 2000, 9, 37-61. doi: 10.3727/000000001783992687

[19] Marmorstein, R.; Zhou, M.M. Writers and readers of histone acetylation: structure, mechanism, and inhibition. Cold Spring Harb. Perspect. Biol. 2014, 6. doi: 10.1101/cshperspect.a018762

[20] Jambhekar, A.; Dhall, A.; Shi, Y. Roles and regulation of histone methylation in animal development. Nat. Rev. Mol. Cell Biol. 2019, 20, 625-641. doi: 10.1038/s41580-019-0151-1

[21] Wang, J. Q.; Yan, F. Q.; Wang, L. H.; Yin, W. J.; Chang, T. Y.; Liu, J. P.; Wu, K. J. Identification of new hypoxia-regulated epithelial-mesenchymal transition marker genes labeled by $\mathrm{H}_{3} \mathrm{~K} 4$ acetylation. Genes Chromosomes Cancer. 2020, 59, 73-83. doi:10.1002/gcc.22802 
[22] Chen, F.; Qi, S.; Zhang, X.; Wu, J.; Yang, X.; Wang, R. IncRNA PLAC2 activated by H3K27 acetylation promotes cell proliferation and invasion via the activation of Wnt/ $\beta$ catenin pathway in oral squamous cell carcinoma. Int J Oncol. 2019, 54, 1183-1194. doi:10.3892/ijo.2019.4707

[23] Almeida, L.O.; Abrahao, A.C.; Rosselli-Murai, L.K.; Giudice, F.S.; Zagni, C.; Leopoldino, A.M. et al. NFkB mediates cisplatin resistance through histone modifications in head and neck squamous cell carcinoma (HNSCC). FEBS open bio. 2013, 4, 96-104. doi: 10.1016/j.fob.2013.12.003

[24] Wang, K.C.; Chang, H.Y. Molecular mechanisms of long non-coding RNAs. Mol. Cell. 2011, 43, 904-914, doi: 10.1016/j.molcel.2011.08.018

[25] Hammond, S.M. MicroRNAs as tumor suppressors. Nat. Genet. 2007, 39, 582-583. doi: 10.1038/ ng0507-582

[26] Schneider, A.; Victoria, B.; Lopez, Y.N.; Suchorska, W.; Barczak, W.; Sobecka, A. et al. Tissue and serum microRNA profile of oral squamous cell carcinoma patients. Sci. Rep. 2018, 8, 675. doi: 10.1038/s41598O17-18945-Z

[27] Sobecka, A.; Barczak, W.; Suchorska, W.M. RNA interference in head and neck oncology. Oncol. Lett. 2016, 12, 3035-3040. doi: 10.3892/ol.2016.5079

[28] Song, J.; Yi, C. Chemical Modifications to RNA: A New Layer of Gene Expression Regulation. ACS Chem. Biol. 2017, 12, 316-325. doi: 10.1021/acschembio.6boog6

[29] Mongan, N.P.; Emes, R.D.; Archer, N. Detection and analysis of RNA methylation. F1oooRes. $2019,8$. doi: 10.12688/f10ooresearch.17956.1

[30] Dominissini, D.; Moshitch-Moshkovitz, S.; Schwartz, S.; Salmon-Divon, M.; Ungar, L.; Osenberg, S. et al. Topology of the human and mouse $\mathrm{m}^{6} \mathrm{~A}$ RNA methylomes revealed by $\mathrm{m}^{6} \mathrm{~A}$-seq. Nature $\mathbf{2 0 1 2}$, 485, 201-206. doi: 10.1038/nature11112

[31] Yue, Y.; Liu, J.; He, C. RNA N6-methyladenosine methylation in post-transcriptional gene expression regulation. Genes Dev. 2015, 29, 1343-1355. doi: 10.1101/gad.262766.115

[32] Ke, S.; Alemu, E.A.; Mertens, C.; Gantman, E.C.; Fak, J.J.; Mele, A. et al. A majority of m6A residues are in the last exons, allowing the potential for 3' UTR regulation. Genes Dev. 2015, 1, 2037-2053. doi: 10.1101/gad.269415.115

[33] Paris, J.; Morgan, M.; Campos, J.; Spencer, G.J.; Shmakova, A.; Ivanova et al. Targeting the RNA m6 Reader YTHDF2 Selectively Compromises Cancer Stem Cells in Acute Myeloid Leukemia. Cell Stem Cell 2019, 3, 137-148. doi: 10.1016/j.stem.2019.03.021

[34] Cui, Q.; Shi, H.; Ye, P.; Li, L.; Qu, Q.; Sun, G. et al. m6 A RNA Methylation Regulates the Self-Renewal and Tumorigenesis of Glioblastoma Stem Cells. Cell Rep. 2017, 14, 2622-2634. doi: 10.1016/j. celrep.2017.02.059

[35] Liu, J.; Ren, D.; Du, Z.; Wang, H.; Zhang, H.; Jin, Y. m6 A demethylase FTO facilitates tumor progression in lung squamous cell carcinoma by regulating MZF1 expression. Biochem. Biophy.s Res. Commun. 2018, 5O2, 456-464. doi: 10.1016/j.bbrc.2018.05.175

[36] Wu, L.; Wu, D.; Ning, J.; Liu, W.; Zhang, D. Changes of N6-methyladenosine modulators promote breast cancer progression. BMC Cancer 2019, 19, 326. doi: 10.1186/s12885-019-5538-z

[37] Chen, M.; Wei, L.; Law, C.T.; Tsang, F.H.; Shen, J.; Cheng, C.L. et al. RNA N6-methyladenosine methyltransferase-like 3 promotes liver cancer progression through YTHDF2-dependent posttranscriptional silencing of SOCS2. Hepatology 2018, 67,2254-2270. doi: 10.1002/hep.29683

[38] Han, J.; Wang, J.Z.; Yang, X.; Yu, H.; Zhou, R.; Lu, H.C. et al. METTL3 promote tumor proliferation of bladder cancer by accelerating pri-miR221/222 maturation in m6A-dependent manner. Mol. Cancer 2019, 22, 110. doi: 10.1186/s12943-019-1036-9

[39] Taketo, K.; Konno, M.; Asai, A.; Koseki, J.; Toratani, M.; Satoh, T. et al. The epitranscriptome m6A writer METTL3 promotes chemo- and radioresistance in pancreatic cancer cells. Int. J. Oncol. 2018, 52, 621629. doi: 10.3892/ijo.2017.4219

[40] Zhao, X.; Cui, L. Development and validation of a $\mathrm{m}^{6} \mathrm{~A}$ RNA methylation regulators-based signature for predicting the prognosis of head and neck squamous cell carcinoma. Am. J. Cancer Res. 2019, 9, 21562169. 